\title{
PENGARUH PEMBERIAN DEAE DEXTRAN DAN PENGATURAN SUHU INKUBASI TERHADAP REPLIKASI VIRUS AVIAN INFLUENZA PADA TELUR AYAM BEREMBRIO
}

\author{
Sapto Rini Budi Prasetyowati*1, Jusak Nugraha ${ }^{2}$, Chairul A. Nidom ${ }^{3}$ \\ 1.2. Prodi S2 Imunologi Sekolah Pascasarjana Universitas Airlangga \\ ${ }^{1.2 .}$ Universitas Airlangga: Jl. Airlangga Surabaya (031) 5041566, 5041536 \\ e-mail: rinifarah14@gmail.com ${ }^{* 1}$
}

\begin{abstract}
Abstrak
Kemampuan replikasi virus Avian Influenza (AI) di telur ayam berembrio (TAB) tidak stabil. Titer virus yang dihasilkan rendah dan sangat bervariasi antar tiap TAB. Suhu inkubasi yang optimal bervariasi untuk masing masing virus AI berkisar $35^{\circ} \mathrm{C}-37^{\circ} \mathrm{C}$. Di-ethyl amino ethyl Dextran (DEAE Dextran) bersifat polikationik sehingga bisa meningkatkan adesi antara virus dan sel embrio. Penelitian ini menggunakan suhu $35^{\circ} \mathrm{C}$ dan suhu $37^{\circ} \mathrm{C}$ serta konsentrasi DEAE Dextran 25 dan 50 mikrogram. Peningkatan replikasi virus diketahui dengan Uji Haemagglutinasi (HA) dan Egg Infectious Dose 50. Hasil uji HA yang dibutuhkan adalah Prosentase titer $H A \geq 128$ HAU. Hasil penelitian dengan analisa Chi-square didapatkan hasil bahwa virus A/chicken/Subang29/clade 2.1.3/Pusvetma 2012 ada hubungan prosentase titer HA $\geq 128$, pada suhu inkubasi $37^{\circ} \mathrm{C}$ dan antara tanpa pemberian Dextran dan dengan pem-berian DEAE Dextran 25 dan 50 mikrogram. Sedangkan virus A/Chicken/Sukoharjo/clade 2.3.2/Pusvetma 2012 menunjukkan adanya hubungan besarnya prosentase titer $H A \geq 128 \mathrm{HAU}$ dengan suhu inkubasi $35^{\circ} \mathrm{C}$ dan pemberian Dextran 25 dan 50 mikrogram. Perbedaan kemampuan replikasi kedua virus tersebut dipengaruhi oleh perbedaan susunan asam amino pada Haemagglutinin yang ditunjukkan dengan homologi antara keduanya adalah 87,8\%-88.1\%. $D E A E$

Dextran berpengaruh positif terhadap peningkatan kemampuan replikasi virus Avian Influenza HPAI A/chicken/Subang29/clade 2.1.3/Pusvetma 2012 dan A/ Chicken /Sukoharjo/clade 2.3.2/Pusvetma 2012 pada suhu inkubasi yang berbeda
\end{abstract}

Keyword: Avian Influenza, DEAE Dextran, Suhu Inkubasi

\section{PENDAHULUAN}

Antigen AI produk Pusvetma berupa

whole virus AI strain tertentu yang inaktif.

Sebagai bahan diagnostik, antigen Pusvetma

diharapkan mempunyai sifat- sifat stabil; akurasi (tepat uji); dan antigennya mudah direplikasi (dikembangkan). Sifat mudah dikembangkan adalah salah satu kendala dalam produksi vaksin dan antigen. Berdasarkan pengalaman di laboratorium 
Jurnal Biosains Pascasarjana Vol. 17 (2015) pp

(C) (2015) Program Pascasarjana Universitas Airlangga, Indonesia

Pusvetma, terdapat perbedaan kemampuan

replikasi di antara virus AI. Virus AI H5N1

yang diisolasi dari daerah Pare yang pertama

muncul pada tahun 2004

(A/Ck/Pare/PVF/2004) relatif lebih cepat

berkembang biak, lebih stabil dan lebih

tinggi jumlah virus yang dihasilkan artinya

lebih mudah bereplikasi. Sifat ini membuat

proses produksi lebih mudah, lebih cepat

dan lebih murah.

Saat ini virus yang beredar di

Indonesia adalah virus AI clade 2.3.1 dan

virus AI clade 2.3.2. (Azhar, 2014; Hendra,

2014). Dalam rangka monitoring virus AI di

Indonesia maka dibutuhkan antisera dan

antigen yang mengandung kedua virus

tersebut. Sesuai tupoksinya maka Pusvetma

melaksanakan pembuatan hiperimmune

serum AI clade 2.1.3 dan clade 2.3.2 di

mana dalam proses produksinya

membutuhkan pembuatan antigen virus AI

clade 2.1.3 dan 2.3.2.

\section{TINJAUAN PUSTAKA}

2.1.Faktor-faktor yang mempengaruhi kemampuan replikasi virus AI
Respon kekebalan telur ayam berembrio; suhu inkubasi dan kelembaban, keseragaman umur embrio, strain virus AI dan kemampuan virus AI bereplikasi pada TAB.

Dalam produksi antigen, hasil uji Haemagglutinasi diharapkan bisa mencapai nilai sama dengan atau lebih besar dari 128 HAU sehingga keseluruhan proses produksi bisa efisien dan efektif. Kemampuan replikasi virus berubah dari waktu ke waktu yang ditunjukkan dengan hasil uji Haemagglutinasi yang cenderung menurun. Oleh karena itu dicari cara untuk bisa menyelesaikan masalah ini. Suhu inkubasi adalah salah satu faktor yang mempengaruhi kemampuan replikasi virus AI pada telur ayam berembrio (TAB). Suhu yang tinggi mempengaruhi kadar penguapan yang terjadi melalui pori kerabang. Keadaan ini mempengaruhi volume alantois. Semakin banyak terjadi penguapan, volume alantois semakin berkurang. Aktifitas yang tinggi dari Haemagglutinasi (HA) dan Neurominidase (NA) membebani embrio dan menyebabkan kematian awal pada 
Jurnal Biosains Pascasarjana Vol. 17 (2015) pp

(C) (2015) Program Pascasarjana Universitas Airlangga, Indonesia

embrio. Kematian awal embrio berpengaruh

terhadap efisiensi produksi. Hasil penelitian

Khalili didapatkan bahwa telur ayam

berembrio yang bisa dipakai lebih banyak jika diinkubasikan pada suhu $35^{\circ} \mathrm{C}$. Hasil

penelitian mengenai suhu inkubasi

berdasarkan analisa statistik, perbedaan suhu

berpengaruh secara signifikan terhadap

aktivitas enzyme polymerase yang

meningkat pada suhu $39^{\circ} \mathrm{C}$ dibandingkan

pada suhu $35^{\circ} \mathrm{C}$ (Lang et al., 2011). Tapi

peneliti lain menulis bahwa titer HA

tertinggi didapatkan jika suhu inkubasi

$34,4^{0} \mathrm{C}$ tergantung strain virus (Khalili,

2013)

\subsection{DEAE Dextran}

Penggunaan senyawa di-ethyl

aminoethyl dextran (DEAE Dextran) untuk meningkatkan kemampuan replikasi virus yang ditunjukkan dengan tingginya titer virus baik dalam EID50 maupun HA. Penambahan inokulum dengan Di-Ethyl Amino Ethyl Dextran (DEAE Dextran) akan meningkatkan titer HA 2 log. DEAE Dextran juga dapat mempermudah partikel virus untuk melekat pada permukaan sel JBP Vol. 17, No. 3, Desember 2015-Sapto Rini Budi Prasetyo karena sifatnya sebagai polikation . Informasi yang lain menyebutkan bahwa DEAE Dextran bertindak sebagai pengikat di permukaan sel sebagai sumber ionik virus untuk melekat. (Hassan et al, 2011)

\section{METODE PENELITIAN}

Telur ayam berembrio yang dipakai adalah Spesifik Antibodi Negatif (SAN) diinokulasi dengan virus AI clade 2.1.3 dan clade 2.3.2. Di-Ethyl Amino Ethyl Dextran (DEAE Dextran) produk dari Sigma kemasan 10 gram. DEAE Dextran diencerkan menjadi $25 \mu \mathrm{g}$ DEAE Dextran/0.1 $\mathrm{ml} \quad$ dan $50 \quad \mu \mathrm{g} \quad$ DEAE Dextran/0.1 ml. Inokulum virus berisi $10^{3}$ EID 50/0.1 ml larutan working seed virus AI clade 2.1.3 dan clade 2.3.2. Besarnya dosis DEAE Dextran ditentukan dari penelitian Eman A. Hassan et al 2011. Inokulasi dilakukan inokulasi DEAE dextran terlebih dahulu $0.1 \mathrm{ml}$, kemudian suspensi virus 0.1 ml. Perlakuan antar strain dilakukan pada waktu yang berbeda untuk mencegah kontaminasi. Telur ayam berembrio yang telah diinfeksi virus $\mathrm{AI}$ H5N1 diberi identitas yang jelas dan diinkubasi pada 
Jurnal Biosains Pascasarjana Vol. 17 (2015) pp

(C) (2015) Program Pascasarjana Universitas Airlangga, Indonesia

suhu $35^{\circ} \mathrm{C}$ dan $37^{\circ} \mathrm{C}$ di dalam inkubator selama dua hari. Pengamatan terhadap keadaan embrio dilakukan setiap jam dengan cara diteropong (candling) untuk memastikan bahwa embrio masih hidup. Telur yang mengandung embrio yang telah mati segera dikeluarkan dari inkubator untuk selanjutnya dimasukkan ke dalam refrigerator bersuhu $4^{\circ} \mathrm{C}$ guna mencegah terjadinya pembusukan. Telur ayam berembrio yang telah disimpan pada suhu $4^{\circ}$ C selama 4-24 jam kemudian dikeluarkan. Bagian kerabang telur didesinfeksi dengan menggunakan alkohol 70\%, kemudian kulit/kerabang telur dikelupas secara aseptik. Membran khorioallantois dan amnion disingkap dan digunting lalu cairan allantoisnya disedot dengan mengunakan spuit secara hati-hati, agar kuning telur tidak ikut terhisap. Masing-masing telur yang dipanen menggunakan spuit yang baru, Setiap spuit diberi tanda sesuai dengan label yang ada pada telur. Hasil panen cairan alantois selanjutnya dibagi dalam wadah steril masing masing $1 \mathrm{cc}$ dan disimpan di suhu $-80{ }^{\circ} \mathrm{C}$ sampai dipergunakan.

\section{UJI HA}

Penyiapan Sel Darah Merah / Red Blood Cell (RBC) Ayam $1 \%$.

Darah ayam segar diambil dengan menggunakan spuit $5 \mathrm{ml}$ melalui vena brachialis, selanjutnya ditampung dalam tabung reaksi yang telah diisi antikoagulan EDTA, dengan dosis $1 \mathrm{mg} / \mathrm{mL}$ darah. Sel darah merah dalam tabung reaksi ditambahkan PBS pH 7,0 kemudian disentrifugasi dengan kecepatan 2000 RPM selama 15 menit. Supernatan dibuang, pellet ditambahkan PBS dan disentifugasi kembali. Hal ini dilakukan sebanyak tiga kali sehingga diperoleh suspensi sel darah merah yang bersih dan dibuat RBC $5 \%$ dan $1 \%$ dengan penambahan PBS pH 7,0.

Metode titrasi virus dengan cara Hemagglutination Assay

(FAO,2014)(OIE,2012)

a. Virus dititrasi pada mikroplate Ubottom 96-well plate.

b. $25 \mu \mathrm{l}$ PBS dimasukkan kedalam seluruh well sesuai jumlah baris yang sudah dihitung untuk mengadakan pengujian. 
Jurnal Biosains Pascasarjana Vol. 17 (2015) pp

(C) (2015) Program Pascasarjana Universitas Airlangga, Indonesia

c. $25 \mu \mathrm{l}$ alantois dimasukkan ke dalam Alantois yang dikumpulkan dari well pertama di masing-masing baris pertama untuk pengujian.

masing masing TAB untuk setiap perlakuan diencerkan secara desimal dalam larutan Pengenceran serial dua kali dari alantois mulai kolom 1 ke kolom 11 dan buang $25 \mu \mathrm{l}$ dari kolom 11 . Kolom 12 sebagai kontrol RBC

d. $25 \mu \mathrm{l}$ PBS dimasukkan ke semua wells yang akan digunakan untuk pengujian.

e. Darah merah ayam (RBC) $1 \%$ dimasukkan ke dalam semua well yang digunakan untuk pengujian, tutup semua plate, goyangkan selama 10 sampai 15 detik.

f. Inkubasi dalam suhu $4{ }^{\circ} \mathrm{C}$ selama 45 sampai 60 menit

g. Periksa plate untuk haemagglutinasi;

Titrasi endpoint adalah pengenceran antigen tertinggi dimana terjadi agglutinasi lengkap. Pada tingkat pengenceran ini, virus dianggap mengandung 1 haemagglutinating unit (HAU) per $25 \mu 1$. khorio alantoiknya diambil untuk dilakukan Metoda titrasi EID 50 (Young,2010) uji hemaglutinasi (HA) untuk memastikan bahwa kematian tersebut disebabkan oleh 
Jurnal Biosains Pascasarjana Vol. 17 (2015) pp

(C) (2015) Program Pascasarjana Universitas Airlangga, Indonesia

virus AI. Penginkubasian dilakukan selama

5 hari, setelah 5 hari semua telur yang masih

tersisa (embrio belum mati) dibunuh dengan

cara menyimpan didalam lemari es pada suhu $4^{\circ} \mathrm{C}$ selama satu malam. Dari setiap telur diambil cairan khorio alantoiknya dan dilakukan uji Hemagglutinasi (HA) satu persatu . Selanjutnya kandungan virus dalam EID50 ditentukan berdasarkan rumus sbb . :

$\mathrm{m}=\mathrm{X} \mathrm{k}+\underline{1} \mathrm{~d}-\mathrm{d} \cdot \sum_{\mathrm{ri}}$
$\mathrm{M}$ = Titik akhir (endpoint) (EID so); $\mathrm{Xk}=$

Nilai log pada garis akhir titrasi (10)

$\mathrm{d}=$ Log - pengenceran dalam hal ini pengenceran 10 kali $(\log 10=1)$;

$\sum \mathrm{r} \mathrm{i}=$ Jumlah semua telur yang tidak terinfeksi; $\mathrm{n}=$ Jumlah telur yang diinokulasi setiap pengenceran ( 5 butir telur)

\section{Analisa data}

Analisa data menggunakan Chisquare karena yang dibandingkan dua variabel yakni hasil uji HA sama dengan atau lebih dari 128 HAU dengan alantois dengan nilai HA dibawah 128 HAU . Tujuannya untuk melihat apakah ada hubungan antara prosentase HA sama JBP Vol. 17, No. 3, Desember 2015—Sapto Rini Budi Prasetyo dengan atau di atas 128 HAU dengan 3 variabel bebas. Dalam penelitian ini variable bebasnya ada 3 , yakni DEAE dextran, Strain virus, dan suhu yang berbeda.

\section{HASIL DAN PEMBAHASAN}

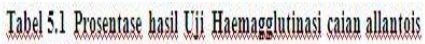 leblih ataus ama dengan $128 \mathrm{HAC}$}

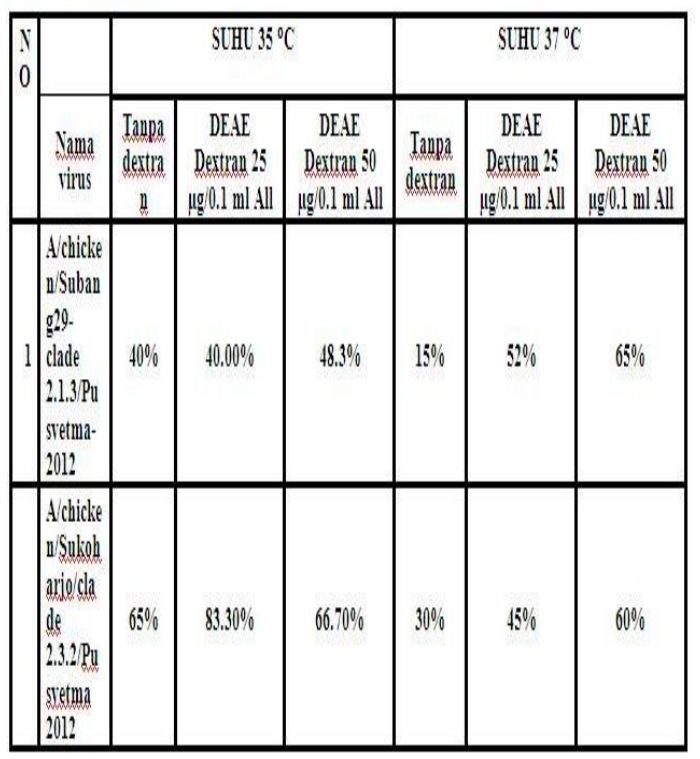

Tabel 5.2 Crosstab dan Chi-square test
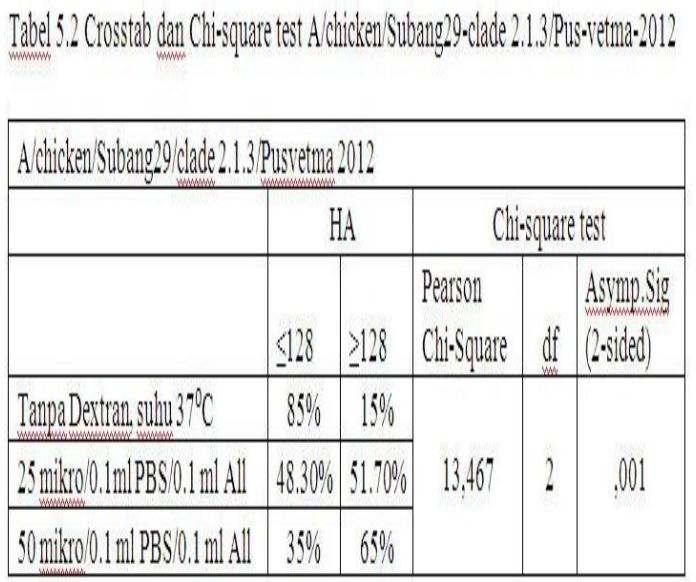

A/chicken/Subang29-clade 2.1.3/Pus-vetma-2012 
Jurnal Biosains Pascasarjana Vol. 17 (2015) pp

(C) (2015) Program Pascasarjana Universitas Airlangga, Indonesia

Ho : Tidak ada hubungan antara prosentase alantois yang mengandung virus di $\geq 128$ HAU dengan perlakuan, pemberian DEAE Dextran 25 dan 50 Mikrogram dengan $0.1 \mathrm{ml}$ alantois, dan tanpa pemberian Dextran jika diinkubasikan pada suhu $37^{\circ} \mathrm{C}$

H1 : ada hubungan antara prosentase alantois yang mengandung virus $\geq 128$

HAU dengan perlakuan, pemberian DEAE Dextran 25 dan 50 Mikrogram dengan $0.1 \mathrm{ml}$ alantois,dan tanpa pemberian Dextran jika diinkubasikan pada suhu $37^{\circ} \mathrm{C}$

Jika Chi-square hitung $<$ Chi-square tabel, maka Ho diterima; Jika Chisquare hitung $>$ Chi-square tabel, maka Ho ditolak; Dari Tabel 5.2, jika $\alpha=0.05, \mathrm{df}=2$ maka Chi-square tabel adalah 5.991, sedangkan pada tabel 5.2 Chisquare hitung adalah 13.467, maka Chisquare > chisquare tabel, sehingga Ho ditolak. Probabilitas atau Asymp hitung adalah 0.01, lebih kecil dari 0.05 maka Ho ditolak. Replikasi virus AI Subang 29 clade 2.1.3 akan meningkat jika inokulum diberi DEAE Dextran dan diinkubasikan pada suhu $37^{\circ} \mathrm{C}$

Tabel 5.3 Hasil analisa Crosstab dan Chirsquare test AChicken Sulohoharioclade 23.2. Pusvetma 2012

\begin{tabular}{|c|c|c|c|c|c|}
\hline \multicolumn{6}{|c|}{ Acliicken/Sukohario /clade 2.3.2Pusvetma2012 } \\
\hline & \multicolumn{2}{|c|}{$\% \mathrm{HA}$} & \multicolumn{3}{|c|}{ Chissquare test } \\
\hline & $\leq 28$ & 2128 & $\begin{array}{l}\text { Pearson } \\
\text { Chir-Square }\end{array}$ & df & $\begin{array}{l}\text { Asvmp.Sit } \\
\text { (2-sided })\end{array}$ \\
\hline 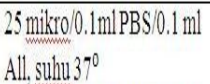 & $55 \%$ & $45 \%$ & \multirow{2}{*}{6.348} & \multirow{2}{*}{1} & \multirow{2}{*}{004} \\
\hline $\begin{array}{l}25 \text { milkrol0. Iml PBS/0.1 ml } \\
\text { All. sulhu } 35^{\circ} \mathrm{C}\end{array}$ & $16.70 \%$ & $83.30 \%$ & & & \\
\hline
\end{tabular}

tabel adalah 3.841, sedangkan pada tabel 5.2 Chisquare hitung adalah 6,438, maka Chisquare hitung > chisquare tabel, sehingga Ho ditolak. Probabilitas atau Asymp hitung adalah 0.004, lebih kecil dari 0.05 maka Ho ditolak. Kesimpulan : ada hubungan antara prosentase alantois yang mengandung virus di atas 128 HAU dengan perlakuan pemberian DEAE Dextran 25 Mikrogram/0.1 ml PBS dengan $0.1 \mathrm{ml}$ alantois, yang diinkubasikan pada suhu $37^{0}$ $\mathrm{C}$ dan $35^{\circ} \mathrm{C}$ 
Jurnal Biosains Pascasarjana Vol. 17 (2015) pp

(C) (2015) Program Pascasarjana Universitas Airlangga, Indonesia

Tabel 5.4. Nilai EID 50 virus

\begin{tabular}{|c|c|c|c|c|c|}
\hline \multicolumn{6}{|c|}{ Hasil EID 50 (Egg Iffectious Dose 50 ) } \\
\hline & \multirow{3}{*}{ Petalakuan } & \multirow{2}{*}{\multicolumn{2}{|c|}{$\begin{array}{c}\text { A chicken Subang29-clade } \\
21.3 \text { Pusvetma-2012. }\end{array}$}} & \multirow{2}{*}{\multicolumn{2}{|c|}{$\begin{array}{c}\text { A Chicken Sukoharjo-clade } \\
\text { 23.2Pusvetma-2012. }\end{array}$}} \\
\hline & & & & & \\
\hline & & Subur $35^{\circ}$ & Suturu $37^{\circ}$ & Sulatu $35^{\circ}$ & Sutura $37^{\circ}$ \\
\hline & ampa dettran & $10^{6.7} 0.1 \mathrm{ml}$ & \multicolumn{2}{|c|}{$10^{5 \cdot 9} 0.1 \mathrm{~m} 10^{6 \cdot 1} 0.1 \mathrm{ml}$} & $10^{6: 3} 0.1 \mathrm{ml}$ \\
\hline & O.Mikrogram DEAE & & \multirow{2}{*}{\multicolumn{2}{|c|}{$10^{7}: 0.1 \mathrm{~m} \cdot 10^{1.5} 0.1 \mathrm{~m}$}} & \\
\hline & extran 0.1 Alantois & $10^{7 / 3} 0.1 \mathrm{ml}$ & & & $10^{677} 0.1 \mathrm{ml}$ \\
\hline & 5.Vikrogram DEAE & & \multirow{2}{*}{\multicolumn{2}{|c|}{$0.1 \mathrm{~m}$}} & \\
\hline & Jextran 0.1 Alatartios & $10^{7 / 3} 0.1 \mathrm{ml}$ & & & $10^{6.5} 0.1 \mathrm{~m} \mathrm{~m}$ \\
\hline
\end{tabular}

Nilai EID 50 diperoleh dari koleksi seluruh alantois masing masing perlakuan dari HA 0 sampai 512. EID50 bukan merupakan hasil pengulangan oleh karena itu dianalisa secara deskriptif. Dari tabel terlihat dari masing masing virus, dan perlakuan suhu inkubasi, nilai EID 50 terkecil adalah perlakuan tanpa DEAE Dextran.

Hasil uji haemaglutinasi virus A/chicken/Subang29/clade 2.1.3 /Pusvetma 2012 menunjukkan adanya hubungan antara prosentase HA lebih atau sama dengan 128 dengan dengan penambahan DEAE Dextran 50 mikro dan 25 mikro dengan inokulum tanpa DEAE dextran. Pada virus AI A/Chicken/Sukoharjo/clade 2.3.2/Pusvetma 2012 ada hubungan antara prosentase HA lebih atau sama dengan 128 HAU dengan penambahan DEAE Dextran 50 mikro dan 25 mikro

Pada penelitian ini DEAE terbukti mempengaruhi kemampuan replikasi virus Avian Influenza sesuai dengan hasil penelitian yang dilakukan oleh Pari dan $\mathrm{Xu}$ pada tahun 2004 yang menggunakan Deae Dextran dalam proses transfeksi DNA ke dalam sel sejak awal tahun 80 an. Penggunaan DEAE Dextran dapat menghemat jumlah DNA yang dipakai sampai 8-14 kali lipat ( Gauss,1992). DEAE Dextran bersifat polikation sehingga memfasilitasi infeksi virus pada sel secara efisien. DEAE dapat berikatan pada permukaan sel sehingga memudahkan perlekatan virus pada sel sehingga ada hubungan antara pemberian DEAE Dextran pada infektifitas virus New Castle disease (Hasaan et al., 2011).

Pada penelitian ini virus AI A/chicken/Sukoharjo/clade 2.3.2/Pusvetma 2012 ada hubungan antara prosentase HA lebih atau sama dengan 128 HAU dengan penambahan DEAE Dextran 50 mikro dan 25 mikro jika diinkubasikan pada suhu $35^{\circ} \mathrm{C}$. 
Jurnal Biosains Pascasarjana Vol. 17 (2015) pp

(C) (2015) Program Pascasarjana Universitas Airlangga, Indonesia

Virus A/chicken/Subang29/clade 2.1.3 telur secara pasti kehilangan air yang /Pusvetma 2012 menunjukkan adanya hu- menguap, keluar melalui kerabang telur bungan antara prosentase HA lebih atau sekitar 10-11\%. Semakin tinggi suhu sama dengan 128 dengan dengan inkubasi maka penguapan akan semakin penambahan DEAE Dextran 50 mikro dan banyak.

25 mikro dengan inokulum tanpa DEAE Sebagian virus lebih menyukai suhu dextran jika diinkubasikan pada suhu $37^{\circ} \mathrm{C} . \quad 35^{\circ} \mathrm{C}$ untuk multiplikasi virus pada Suhu inkubasi berpengaruh pada membrane alantois dengan penyebab yang pertumbuhan virus. Lang et al (2011) Suhu belum diketahui (Khalili et al.,2013). Seperti $37^{\circ} \mathrm{C}$ mempengaruhi aktivitas polymerase pada hasil penelitian ini virus AI viral, dan mendorong kecepatan A/chicken/Sukoharjo/clade 2.3.2/Pusvetma pertumbuhan embrio. Aktifitas polymerase virus meningkatkan replikasi virus AI. Suhu inkubasi juga berpengaruh pada aktifitas trypsin like protease yang ada pada cairan alantois dan amniotic. Protease membelah HA pada LPAI pada temperature di atas $35^{\circ} \mathrm{C}$. Hasilnya adalah meningkatnya perlekatan virus pada sel epitel dan meningkatnya replikasi virus pada sel epitel dan meningkatkan replikasi pada $\mathrm{TAB}$ umur 10, sebaliknya pada umur 14 hari aktifitas protease merusak protein HA virus Avian Influenza. Khalili menuliskan bahwa temperature berpengaruh pada jumlah alantois. Hal ini disebabkan karena semua 2012 ada hubungan antara prosentase HA lebih atau sama dengan 128 HAU dengan penambahan DEAE Dextran 50 mikro dan 25 mikro jika diinkubasikan pada suhu $35^{\circ} \mathrm{C}$

\section{KESIMPULAN}

Penambahan DEAE Dextran berpengaruh positif pada kemampuan replikasi kedua virus dengan suhu inkubasi yang berbeda. Dengan mengetahui pola replikasi virus AI untuk bisa mencapai titer HA sama dengan atau lebih dari 128 HAU dengan prosentase yang tinggi maka dalam produksi antigen selanjutnya akan digunakan DEAE Dextran JBP Vol. 17, No. 3, Desember 2015—Sapto Rini Budi Prasetyo 
Jurnal Biosains Pascasarjana Vol. 17 (2015) pp

(C) (2015) Program Pascasarjana Universitas Airlangga, Indonesia

dengan penyesuaian suhu inkubasi se-

suai dengan jenis virusnya. Dalam In-

dustri produksi vaksin dan antigen, per-

kembangan virus AI demikian cepat di

Indonesia maka diperlukan penelitian

terhadap setiap virus strain baru untuk

mengetahui kemampuan replikasi virus

secara optimal.

\section{DAFTAR PUSTAKA}

Azhar M.,2014. "Perkembangan Kasus AI pada Unggas dan Kematian Itik akibat AI sampai dengan 31 Januari 2014”. Technical Briefing Meeting ke 10 Ditkeswan - FAO, 7 Februari 2014

Dhamayanti NLPI,, Hartawan R, Hewajuli DA, Hardiman, Wibawa $\mathrm{H}$, Pudjiatmoko. 2013. “"Karakteristik Molekuler dan Patogenesitas Virus H5N1 clade 2.3.2 asal Indonesia. JITV Vol. 18 No2 Th. 2013: 99-113

Gauss G., and Lieber M.R., "DEAE-dextran enhances electroporation of mammalian cells". 1992. Nucleic Acids Research, 1992, Vol. 20, No. 24 6739-6740

Hassan,E.A, Wanis, N.A and Susan K. Tolba. 2011. "Study Of Incorporation Deae Dextran During Production Of Local Avian Influenza (Ai) Inactivated Vaccine" Egypt. J. Agric. Res., 89 (3), 2011

FAO, OFFLU. 2010."Prescreen HI protocol". Prescreen HI Protocol Training
Khalili, I, Ghadimipour,R, Ameghi,A, Sedigh-Eteghad, S. 2013. "Optimization of incubation temperature in embryonated chicken eggs inoculated with H9N2 vaccinal subtype of avian influenza virus". Veterinary Research Forum. 2013; 4 (3) 145 -. 148. Journal Homepage: vrf.iranjournals.ir

Lang, V.,Marjuki,V., Krauss,S.L., Webby R.J., and. Webste R.G. 2011. "Different Incubation Temperatures Affect Viral Polymerase Activity And Yields Of Low-Pathogenic Avian Influenza Viruses In Embryonated Chicken Eggs". Arch Virol. 2011 June ; 156(6): 987-994.

Nongluk.S., and Yasuo Suzuki. 2012. "Molecular basis of the structure and function of $\mathrm{H} 1$ hemagglutinin of influenza virus". Proc. Jpn. Acad., Ser. $\quad$ B88(2012) doi: $\quad 10.2183$ /pjab.88.226

OIE Terrestrial Manual.2012. Chapter 2.3.4. Avian influenza

Pari G.S.,Xu Y., 2004. "Gene Transfer into Mammalian Cells Using Calcium Phospat dan DEAE Dextran. Methodes" in Molecular Biology. Vol 245. Humana Peress Inc.

Wibawa H. 2014. "Genetic and antigenic mapping of H5N1 HPAI virus in Indonesia, 2008 - 2013”. Technical Briefing Meeting ke 10 DitkeswanFAO, 7 Februari 2014

Young M., Alders R., Grimes S., Spradbrow P., Dias P., da Silva A. and Lobo Q. 2012. "Controlling Newcastle disease in village chickens" A laboratory manual. 2nd edn. ACIAR Monograph No. 87. Australian Centre for International Agricultural 
Jurnal Biosains Pascasarjana Vol. 17 (2015) pp

(C) (2015) Program Pascasarjana Universitas Airlangga, Indonesia

JBP Vol. 17, No. 3, Desember 2015-Sapto Rini Budi Prasetyo 